\title{
Produção Animal em Pastagem com Gramíneas de Estação Quente
}

\author{
João Restle ${ }^{1}$, Cledson Roso ${ }^{2}$, Valmir Aita ${ }^{3}$, José Laerte Nörnberg ${ }^{4}$, Ivan Luiz Brondani ${ }^{5}$, \\ Liliane Cerdótes $^{6}$, Charles de Oliveira Carrilho ${ }^{7}$
}

RESUMO - Foi avaliado o desempenho de novilhos de corte, durante a fase de recria, em capim-elefante (Pennisetum purpureum Schum.) cv. Taiwan A-146, papuã (Brachiaria plantaginea (Link) Hitchc), sorgo forrageiro (Sorghum bicolor (L.) Moench) cv. AG 2501C e milheto (Pennisetum americanum (L.) Leeke) cv. comum. O período total de pastejo foi de 143 dias para a pastagem de capim-elefante e 98 dias para as demais pastagens. O sistema de pastejo foi o contínuo com lotação variável. O teor de proteína bruta na massa de forragem foi de 5,43; 10,08; 9,95; e 10,58\% e a digestibilidade in vitro da matéria seca, de 50,93; 55,85; 54,56; e 54,81\% para capim-elefante, papuã, sorgo e milheto, respectivamente. Houve diferença significativa no ganho de peso médio diário, que foi de 0,928 ; 1,054; 1,121; e 1,188 kg, para o capim-elefante, papuã, sorgo e milheto, respectivamente. Não houve diferença significativa na carga animal entre as pastagens, sendo de 1682, 1634, 1389 e $1514 \mathrm{~kg}$ de PV/ha, e no ganho de peso vivo, que foi de 774, 668, 570 e $640 \mathrm{~kg}$ de PV/ha para as pastagens de capim-elefante, papuã, sorgo e milheto, respectivamente. A utilização de pastagens cultivadas de verão, manejadas corretamente, permite altos ganhos de peso por animal e por área, constituindo-se em uma excelente alternativa para intensificar a produção de bovinos de corte.

Palavras-chave: capim-elefante, milheto, papuã, pastejo, sorgo

\section{Animal Performance in Summer Grasses Pastures}

\begin{abstract}
The performance, during the summer of beef steers grazing elephantgrass (Pennisetum purpureum Schum.), alexandergrass (Brachiaria plantaginea (Link) Hitchc), sorghum (Sorghum bicolor (L.) Moench) and millet (Pennisetum americanum (L.) Leeke) was evaluated. The grazing period for the elephantgrass occurred from 12/04/93 until 04/26/94, and for the other grasses occurred from 01/04/94 until 04/12/94. The total period of grazing was of 143 days for the elephantgrass and of 98 days for the other pastures. The continuous grazing system with variable stocking rate was used. The crude protein of the forage mass was $5.43,10.08$, 9.95 and $10.58 \%$ and "in vitro" dry matter digestibility was $50.93,55.85,54.56$ and $54.81 \%$ for elephantgrass, alexandergrass, sorghum and millet, respectively. Significant difference was observed for average daily weight gain which was $.928,1.053,1.121$ and $1.188 \mathrm{~kg}$ for elephantgrass, alexandergrass, sorghum and millet. No significant difference was observed for stocking rate $(1,682,1,634,1,388$ and $1,541 \mathrm{~kg}$ of live weight/ha) and for live weight gain which was $774,668,570$ and $640 \mathrm{~kg} / \mathrm{ha}$ for the pasture of elephantgrass, alexandergrass, sorghum and millet, respectively. The use of summer cultivated pastures with correct management, allows high weight gains per animal and per area, being an alternative for intensive beef cattle production.
\end{abstract}

Key Words: alexandergrass, elephantgrass, grazing, millet, sorghum

\section{Introdução}

Aumentar a produtividade da pecuária de corte no Rio Grande do Sul é uma necessidade para tornar os sistemas produtivos mais competitivos e viáveis economicamente, uma vez que esta ainda apresenta índices de produtividade muito baixos (Anualpec, 2000), devido, principalmente, à deficiência na alimentação, seja em quantidade ou qualidade.
Para fornecer forragem de alto valor nutritivo ao rebanho bovino durante o inverno, pois o campo nativo apresenta baixa produção e qualidade de forragem neste período, é comum a utilização de pastagens cultivadas de estação fria (Roso et al. 2000; Roso \& Restle, 2000). Por outro lado, no período de verão, a base da alimentação é o campo nativo, que apresenta baixa qualidade de forragem (Alves Filho, 1995), sendo insuficiente para manter os

\footnotetext{
${ }^{1}$ Engo‥-Agro , Ph.D., Pesquisador do CNPq, Professor Titular, Departamento de Zootecnia da UFSM, CEP: 97119 - 900 - Santa Maria RS. E.mail: jorestle@ccr.ufsm.br Fone: (055) 2208084

2 Engㅇ․-Agro, Mestre em Zootecnia, PROGEPEC Consultores Associados Ltda. Santa Maria - RS.

${ }^{3}$ Engo-.-Agro-, Mestre em Zootecnia, Professor Colégio Agrícola de Santa Maria - RS.

${ }^{4}$ Médico Veterinário, MSc, Professor Assistente, Departamento de Tecnologia e Ciência dos Alimentos da UFSM.

5 Zootecnista, MSc, Professor Assistente do Departamento de Zootecnia da UFSM.

6 Zootecnista, Aluna de Mestrado em Zootecnia da UFSM.

${ }^{7}$ Acadêmico do curso de Zootecnia da UFSM. Bolsista IC - FAPERGS.
} 
requerimentos nutricionais das categorias mais exigentes (NRC, 1996), o que limita o desempenho dos animais, retardando a idade de abate dos machos e o primeiro acasalamento das fêmeas. Segundo Vaz (1998), o campo nativo apresentou, durante o verão, DIVMO de $39 \%$ e proteína bruta de $7,1 \%$, com disponibilidade de $2128 \mathrm{~kg}$ de MS/ha. Nesse aspecto, a implantação de pastagens cultivadas de verão constitui-se em excelente alternativa para fornecer forragem de melhor qualidade (Restle et al., 1996; Muehlmann et al., 1997), visando maximizar o potencial de ganho de peso dos animais, otendo-se, assim, maior eficiência no sistema produtivo.

As espécies mais usadas como pastagens de estação quente são o milheto e o capim-elefante. No entanto, culturas alternativas podem ser usadas neste período, como o sorgo forrageiro e o capim-papuã.

O capim-elefante é largamente utilizado para rebanhos leiteiros, normalmente sob a forma de pastejo rotativo, mas tem apresentado bom potencial, quando utilizado em pastejo contínuo (Kessler, 1995; Muehlmann et al., 1997). O sorgo tem surgido como substituto do milheto em regiões com adversidade climática, não existindo diferenças no ganho de peso médio diário (GMD) entre sorgo e milheto (Dunavin, 1970; Utley et al., 1976; Coser \& Maraschin, 1983). Já o papuã é considerado uma planta invasora nas culturas de verão, apresentando elevado potencial de produção de sementes, surgindo facilmente em cultivos subseqüentes. Além desta característica, o papuã apresenta elevada produção de massa verde/ha, com boas características qualitativas (Lançanova et al., 1988a,b; Martins et al., 2000), o que o torna altamente promissor como forrageira, principalmente em áreas com rotação de lavoura e pecuária.

$\mathrm{O}$ experimento foi conduzido com o objetivo de comparar espécies forrageiras de estação quente utilizadas no sul do país, quanto ao potencial de produção animal, visando buscar informações para serem adaptadas aos sistemas de produção mais intensivos.

\section{Material e Métodos}

O experimento foi conduzido no período 04/12/93 a 26/04/1994, na área experimental do Departamento de Zootecnia da Universidade Federal de Santa Maria, situada na Depressão Central do Rio Grande do Sul, numa altitude de $95 \mathrm{~m}$, latitude $29^{\circ} 43^{\prime}$ sul e longitude $53^{\circ} 42^{\prime}$ oeste. O solo da área experimental é classificado como Brunizem
Hidromórfico, enquadrando-se na unidade de mapeamento Santa Maria. O clima da região é Cfa (subtropical úmido), conforme classificação de Köppen (Moreno, 1961).

Foram avaliadas diferentes pastagens de estação quente, sendo capim-elefante (Pennisetum purpureum Schum.) cv. Taiwan A-146, papuã (Brachiaria plantaginea (Link) Hitchc), sorgo forrageiro (Sorghum bicolor (L.) Moench) cv. AG 2501C e milheto (Pennisetum americanum (L.) Leeke) cv. comum.

Foram utilizados 32 novilhos "testers" das raças Charolês (C), Nelore (N) e produtos F1 de seu cruzamento e um número variável de animais reguladores de mesmos grupos genéticos, com idade média inicial de 14 meses e peso médio inicial de $211 \mathrm{~kg}$. Em cada tratamento foram utilizados oito animais "testers", distribuídos em duas repetições (piquetes de 1 ha), de acordo com o grupo genético e peso inicial em cada tratamento, visando sua uniformização. Cada repetição constou de um animal $\mathrm{C}, \mathrm{N}, 1 / 2 \mathrm{CN}$ e $1 / 2$ NC. Os animais tiveram livre acesso a um cocho com cloreto de sódio mais fosfato bicálcico (1:1).

O preparo do solo para semeadura das espécies anuais constou de uma aração e três gradagens em novembro de 1993. O capim-elefante havia sido implantado em 1990, sendo utilizado para pastejo e diferido no final do verão que antecedeu este experimento.

A semeadura foi realizada em 23/11, utilizando 10, 30 e $15 \mathrm{~kg}$ de sementes viáveis/ha de papuã, sorgo e milheto, respectivamente. As sementes de sorgo e o milheto foram semeadas em linhas espaçadas de $20 \mathrm{~cm}$, enquanto as sementes de papuã foram semeadas a lanço e incorporadas com grade de dentes. O capim-elefante foi roçado em julho de 1993, a uma altura de $20 \mathrm{~cm}$ do solo.

$\mathrm{Na}$ adubação de base, utilizaram-se $300 \mathrm{~kg} / \mathrm{ha}$ de adubo da fórmula $05-30-15$, distribuídos por ocasião da semeadura das espécies, e em 28/09/93 no capimelefante. Em cobertura, utilizaram-se $300 \mathrm{~kg}$ de N/ha, na forma de uréia, parcelados em quatro aplicações para o sorgo, milheto e papuã e cinco aplicações para o capim-elefante.

O período de pastejo foi diferenciado de acordo com a espécie, sendo de 04/12/93 a 26/04/94 (143 dias) para o capim-elefante, de 04/01 a 12/04/94 (98 dias) para o sorgo e milheto e de 11/01 a 19/04/94 (98 dias) para o papuã. Esta diferença aconteceu porque o capim-elefante, por ser uma espécie perene, implantada em anos anteriores, apresentava bom crescimento em novembro. Já o sorgo, milheto e papuã tiveram que ser implantados em 23/11. 
O método de pastejo foi o contínuo com lotação variável, empregando a técnica de Put and take (Mott \& Lucas, 1952). O ajuste da carga animal foi feito por ocasião das avaliações e durante o período de pastejo, visando manter uma quantidade de folhas que permitissem boa disponibilidade e qualidade de forragem para o máximo desempenho animal. Procurou-se manter uma disponibilidade de forragem de $2000 \mathrm{~kg}$ de $\mathrm{MS} /$ ha para o sorgo e milheto (Moraes \& Maraschin, 1988), adotando o mesmo critério para o capim-papuã. Para o capim-elefante, a massa de folhas inicial pretendida foi de $1000 \mathrm{~kg}$ de MS de folhas/ha.

A avaliação da produção animal foi realizada em cinco períodos, por meio de pesagens, conforme segue: primeiro período: capim-elefante (pesagens em 04/12 e 04/01); segundo período: capim-elefante, sorgo e milheto (pesagens em 04/01 e 01/02), papuã (pesagens em 11/01 e01/02); terceiro período: capimelefante, papuã, sorgo e milheto (pesagens em 01/02 e 01/03); quarto período: capim-elefante, papuã, sorgo e milheto (pesagens em 01/03 e 29/03); e quinto período: capim-elefante (pesagens em 29/03 e 26/04), sorgo e milheto (29/03 e 12/04), papuã, (29/03 e 19/04). As pesagens foram precedidas de um jejum de seis horas.

O ganho de peso médio diário (GMD) dos animais foi obtido pela diferença entre o peso final e inicial dos animais testers em cada período experimental, dividido pelo número de dias do período. A carga animal por período foi calculada pelo somatório do peso médio dos animais testers, com o peso médio dos reguladores, multiplicado pelo número de dias que os últimos permaneceram na pastagem, dividido pelo número de dias do período de pastejo, sendo expressa em $\mathrm{kg}$ de peso vivo/ha (Mott \& Lucas, 1952).

Para determinar a massa de forragem, foram realizadas avaliações na pastagem, dois dias antes das datas das pesagens, por intermédio do corte de 10 amostras de $0,25 \mathrm{~m}^{2}$, tomadas ao acaso na área. Por ocasião das avaliações, retirava-se uma amostra composta para posterior determinação da proteína bruta e digestibilidade in vitro da matéria seca (DIVMS).

$\mathrm{O}$ delineamento experimental utilizado foi o inteiramente casualizado com duas repetições (piquetes). Os dados de GMD, carga anima e ganho de peso vivo/ha foram submetidos à análise de variância e as diferenças entre as médias, comparadas pelo teste Tukey, em nível de 5\% de probabilidade. O modelo estatístico foi constituído pelo tratamento e erro experimental. Efetuou-se a análise da variância por intermédio do pacote estatístico SAS (SAS, 1990).

\section{Resultados e Discussão}

As variáveis avaliadas na pastagem encontram-se nas Tabelas 1 e 2 . A massa de forragem disponível, embora tenha sido previamente estipulada, apresentou pequenas variações ao longo do período de utilização da pastagem, que não devem ter limitado o consumo de forragem pelos animais.

A elevada massa de forragem disponível no capim-elefante $(3626 \mathrm{~kg}$ de $\mathrm{MS} / \mathrm{ha})$ deve-se à alta quantidade de colmos presentes na pastagem, sendo que a quantidade média de forragem disponível de MS de folhas verdes/ha foi de $1168 \mathrm{~kg}$. A massa de forragem obtida neste trabalho assemelha-se à encontrada por Muehlmann et al. (1997), o qual não considerou os componentes material morto e inços na massa de forragem, fazendo com que a disponibilidade de forragem para os animais fosse distinta. Já a quantidade de folhas disponível de $1168 \mathrm{~kg}$ de MS obtidas neste experimento foi superior aos $300 \mathrm{~kg}$ de MS/ha obtido por Muehlmann et al. (1997).

A utilização de massa de forragem total, avaliada rente ao solo, como ferramenta para ajuste da carga animal em capim-elefante, não é totalmente correta, pois grande parte dessa massa pode ser formada por colmos - órgãos rejeitados para consumo pelos animais. Almeida et al. (2000a), trabalhando com ofertas de forragem de 3,8; 7,5; 10,2; e $14 \mathrm{~kg}$ de MS de lâminas verdes $/ 100 \mathrm{~kg}$ de peso vivo/dia em capim-elefante anão "Mott", obteve massa de forragem de lâminas verdes de $722 \pm 10 ; 1537 \pm 65 ; 2332 \pm 2$ e $2542 \pm 36 \mathrm{~kg} / \mathrm{ha}$, respectivamente. Segundo os mesmos autores, a redução na massa de forragem levou à maior participação de outras espécies na pastagem, redução na produção de afilhos, diminuição da biomassa radicular, diminuição na porosidade e aumento na densidade aparente do solo, levando à menor produção de MS/ha/dia. Isso mostra que, ao se trabalhar com baixa oferta de forragem de lâminas verdes, que é o principal órgão de interceptação da radiação solar para produção de fotossintatos, há degradação gradativa da pastagem.

$\mathrm{Na}$ pastagem de papuã, houve aumento na massa de forragem disponível com o passar dos períodos de utilização, ficando na média com $2783 \mathrm{~kg}$ de MS/ha, sendo superior às encontradas nas pastagens de sorgo (2039 kg) e milheto $(2260 \mathrm{~kg})$; essas diferenças deveriam ter sido eliminadas com o manejo da pastagem. O aumento na massa de forragem da pastagem de papuã ocorreu principalmente pelo acúmulo de 
Tabela 1 - Massa de forragem (kg MS/ha), teor de proteína bruta (\%), digestibilidade in vitro da matéria seca (\%), em diferentes pastagens de estação quente

Table 1 - Forage mass (kg DM/ha), crude protein (\%), "in vitro" dry matter digestibility (\%), in different summer pastures

\begin{tabular}{|c|c|c|c|c|c|c|}
\hline \multirow[b]{2}{*}{$\begin{array}{l}\text { Pastagens } \\
\text { Pastures }\end{array}$} & \multicolumn{5}{|c|}{$\begin{array}{l}\text { Períodos } \\
\text { Periods }\end{array}$} & \multirow[b]{2}{*}{$\begin{array}{l}\text { Média } \\
\text { Mean }\end{array}$} \\
\hline & 1 & 2 & 3 & 4 & 5 & \\
\hline \multicolumn{7}{|c|}{$\begin{array}{c}\text { Massa de forragem total } \\
\text { Total forage mass }\end{array}$} \\
\hline $\begin{array}{l}\text { Capim-elefante } \\
\text { Elephantgrass }\end{array}$ & 3428 & 2874 & 3595 & 4108 & 4126 & 3626 \\
\hline $\begin{array}{l}\text { Papuã } \\
\text { Alexandergrass }\end{array}$ & - & 2200 & 2788 & 3281 & 2864 & 2783 \\
\hline $\begin{array}{l}\text { Sorgo } \\
\text { Sorghum }\end{array}$ & - & 1408 & 2260 & 2230 & 2258 & 2039 \\
\hline $\begin{array}{l}\text { Milheto } \\
\text { Millet }\end{array}$ & - & 2200 & 2850 & 2068 & 1921 & 2260 \\
\hline \multicolumn{7}{|c|}{$\begin{array}{l}\text { Proteína bruta } \\
\text { Crude protein }\end{array}$} \\
\hline $\begin{array}{l}\text { Capim-elefante } \\
\text { Elephantgrass }\end{array}$ & 5,60 & 5,35 & 6,15 & 5,60 & 4,45 & 5,43 \\
\hline $\begin{array}{l}\text { Papuã } \\
\text { Alexandergrass }\end{array}$ & - & 11,70 & 10,15 & 9,30 & 9,15 & 10,08 \\
\hline $\begin{array}{l}\text { Sorgo } \\
\text { Sorghum }\end{array}$ & - & 12,75 & 10,05 & 8,50 & 8,50 & 9,95 \\
\hline $\begin{array}{l}\text { Milheto } \\
\text { Millet }\end{array}$ & - & 13,30 & 9,35 & 9,65 & 10,00 & 10,58 \\
\hline \multicolumn{7}{|c|}{ DIVMS } \\
\hline $\begin{array}{l}\text { Capim-elefante } \\
\text { Elephantgrass }\end{array}$ & 57,85 & 51,45 & 50,75 & 48,35 & 46,25 & 50,93 \\
\hline $\begin{array}{l}\text { Papuã } \\
\text { Alexandergrass }\end{array}$ & - & 68,30 & 59,00 & 49,40 & 46,70 & 55,85 \\
\hline $\begin{array}{l}\text { Sorgo } \\
\text { Sorghum }\end{array}$ & - & 67,50 & 55,90 & 48,55 & 46,30 & 54,56 \\
\hline $\begin{array}{l}\text { Milheto } \\
\text { Millet }\end{array}$ & - & 68,55 & 56,75 & 48,50 & 45,45 & 54,81 \\
\hline
\end{tabular}

colmos, pois os animais pastejam o extrato superior da pastagem, onde o material é mais tenro e de melhor qualidade nutritiva, rejeitando o extrato inferior. A massa de forragem média obtida no milheto foi levemente inferior à encontrada por Lupatini (1996), que trabalhou com níveis de nitrogênio, obtendo massa de forragem de $2586 \mathrm{~kg}$ de $\mathrm{MS} /$ ha na média dos tratamentos. Já os resultados obtidos por Cóser \& Maraschin (1983) e Moraes \& Maraschin (1988), na pressão de pastejo de $10 \%$, foram inferiores ao obtido neste experimento.

Verifica-se que o teor de proteína bruta da forragem disponível (Tabela 1) foi semelhante entre as pastagens de papuã, sorgo e milheto, sendo superior ao teor de PB obtido no capim-elefante, apresentando na média do período experimental valores de 5,43; 10,08; 9,95; e
$10,58 \%$, respectivamente, para capim-elefante, papuã, sorgo e milheto. $\mathrm{O}$ baixo valor obtido no capim-elefante deve-se ao baixo teor de proteína bruta encontrado nos colmos (3,37\%), que tiveram elevada participação na forragem disponível, uma vez que a porção folha apresentou teor de proteína bruta de 10,19\% (Tabela 2). Já para o sorgo e milheto, o teor de proteína bruta nos colmos foi de 6,7 e 7,4\%, respectivamente.

$\mathrm{O}$ teor de PB obtido na massa de forragem total do capim-elefante foi superior aos 3,81\% obtidos por Muehlmann et al. (1997), devido à maior quantidade de folhas presente na forragem deste experimento. No entanto, o teor de PB da porção folhas foi inferior ao encontrado pelos mesmos autores (12,85\%). Esta diferença ocorreu devido à maior porção de folhas presente na forragem deste experimento, tendo par- 
Tabela 2 - Massa de forragem (kg MS/ha), teor de proteína bruta (\%), digestibilidade in vitro da matéria seca (\%) de folha e colmo na pastagem de capim-elefante

Table 2 - Forage mass (kg DM/ha), crude protein (\%), "in vitro" dry matter digestibility (\%) of leaf and stem in elephantgrass pasture

\begin{tabular}{|c|c|c|c|c|c|c|}
\hline \multirow[b]{2}{*}{$\begin{array}{l}\text { Pastagens } \\
\text { Pastures }\end{array}$} & \multicolumn{5}{|c|}{$\begin{array}{l}\text { Períodos } \\
\text { Periods }\end{array}$} & \multirow[b]{2}{*}{$\begin{array}{l}\text { Médic } \\
\text { Mean }\end{array}$} \\
\hline & 1 & 2 & 3 & 4 & 5 & \\
\hline $\begin{array}{l}\text { Massa de forragem } \\
\text { Forage mass }\end{array}$ & 1518 & 840 & $\begin{array}{c}\text { Folha } \\
\text { Leaf } \\
1124\end{array}$ & 1280 & 1077 & 1168 \\
\hline $\begin{array}{l}\text { Proteína bruta } \\
\text { Crude protein }\end{array}$ & 8,30 & 9,60 & 11,85 & 11,00 & 10,20 & 10,19 \\
\hline $\begin{array}{l}\text { DIVMS } \\
\text { IVDMD }\end{array}$ & 60,10 & 58,80 & $\begin{array}{l}60,25 \\
\text { Caule } \\
\text { Stem }\end{array}$ & 55,65 & 53,10 & 57,58 \\
\hline $\begin{array}{l}\text { Massa de forragem } \\
\text { Forage mass }\end{array}$ & 1518 & 840 & 1124 & 1280 & 1077 & 1168 \\
\hline $\begin{array}{l}\text { Proteína bruta } \\
\text { Crude protein }\end{array}$ & 3,35 & 2,80 & 3,25 & 3,75 & 3,70 & 3,37 \\
\hline $\begin{array}{l}\text { DIVMS } \\
I V D M D\end{array}$ & 57,95 & 51,10 & 46,25 & 46,45 & 49,90 & 50,33 \\
\hline
\end{tabular}

ticipação de folhas mais velhas, que apresentam menor valor nutritivo.

O percentual de proteína bruta encontrado na pastagem de papuã foi superior aos encontrados por Martins et al. (2000), que obtiveram 4,45; 6,68; e $7,95 \%$ de $\mathrm{PB}$ para os níveis de 0,100 e $200 \mathrm{~kg} / \mathrm{ha}$ de $\mathrm{N}$, respectivamente; Lançanova et al. (1988b), que trabalharam com frequência de corte, obtiveram 7,57 e $3,37 \%$ de PB para o corte a cada seis semanas e floração plena, respectivamente. Já o teor de PB encontrado no milheto foi inferior aos valores obtidos por Lupatini (1996), em todos os nível de $\mathrm{N}$ utilizados, e Lupatini et al. (1996), nos níveis de 150 e 300 kg/ha de N.

Resultados semelhantes para percentual de DIVMS foram encontrados entre as pastagens de papuã, sorgo e milheto, sendo de 55,85; 54,56; e $54,81 \%$, respectivamente. Estes valores foram superiores aos obtidos na pastagem de capim-elefante $(50,93 \%)$. Isto ocorreu devido à baixa digestibilidade da porção colmo presente na massa de forragem do capim-elefante.

A DIVMS obtida no papuã foi superior aos valores encontrados por Martins et al. (2000), que obtiveram 43,68; 46,72; e 45,94\% de DIVMO para os níveis de 0,100 e $200 \mathrm{~kg} / \mathrm{ha}$ de $\mathrm{N}$, respectivamente. No entanto, Lançanova et al. (1988a) obtiveram 70,7 e 55,6\% para a forragem cortada a cada 28 e 84 dias, respectivamente, mostrando que cortes mais freqüentes favorecem o acúmulo de forragem de melhor qualidade.

Os valores de PB e de DIVMS obtidos nas diferentes pastagens decresceram com o passar dos períodos de pastejo, concordando com a afirmação de McCarter \& Rouquette Jr. (1977) e Blaser (1964) de que as espécies forrageiras perdem qualidade nutricional com o avanço no ciclo produtivo, devido ao acúmulo de material estrutural.

$\mathrm{Na}$ Tabela 3, encontram-se os resultados do desempenho dos animais. Houve diferença significativa entre os tratamentos. O GMD obtido no milheto e no sorgo foi superior ao do capim-elefante. Já o papuã apresentou comportamento intermediário, sendo semelhante ao milheto, sorgo e capim-elefante. Os maiores GMD encontrados para o milheto e sorgo correspondem aos maiores valores de PB e DIVMS obtidos nas avaliações das pastagens. Este fato mostra que o desempenho animal é reflexo da qualidade da forragem ingerida, desde que a disponibilidade de forragem não seja fator limitante para consumo. Neste trabalho, a massa de forragem disponível permitiu que os animais selecionassem uma dieta adequada em qualidade e quantidade.

O menor GMD observado no capim-elefante, em relação ao milheto e sorgo, foi ocasionado principalmente pelo baixo GMD obtido no primeiro período de 
Tabela 3 - Ganho de peso médio diário $(\mathrm{kg})$ de novilhos de corte em pastejo em diferentes pastagens de estação quente Table 3 - Average daily weight gain $(\mathrm{kg})$ of beef steers grazing different summer pastures

\begin{tabular}{|c|c|c|c|c|c|c|}
\hline \multirow[b]{2}{*}{$\begin{array}{l}\text { Pastagens } \\
\text { Pastures }\end{array}$} & \multicolumn{5}{|c|}{$\begin{array}{l}\text { Períodos } \\
\text { Periods }\end{array}$} & \multirow[t]{2}{*}{$\begin{array}{c}\text { Média ponderada } \\
\text { Weighed mean }\end{array}$} \\
\hline & 1 & 2 & 3 & 4 & 5 & \\
\hline $\begin{array}{l}\text { Capim-elefante } \\
\text { Elephantgrass }\end{array}$ & 0,605 & 1,103 & 1,098 & 1,036 & 0,835 & $0,928^{b}$ \\
\hline $\begin{array}{l}\text { Papuã } \\
\text { Alexandergrass }\end{array}$ & - & 1,107 & 1,178 & 0,996 & 0,911 & $1,054^{\mathrm{ab}}$ \\
\hline $\begin{array}{l}\text { Sorgo } \\
\text { Sorghum }\end{array}$ & - & 1,295 & 1,330 & 1,112 & 0,370 & $1,121^{\mathrm{a}}$ \\
\hline $\begin{array}{l}\text { Milheto } \\
\text { Millet }\end{array}$ & - & 1,353 & 1,205 & 1,138 & 0,920 & $1,188^{\mathrm{a}}$ \\
\hline
\end{tabular}

a,b Médias seguidas por letras minúsculas diferentes, na coluna, diferem $(P<0,05)$ pelo teste Tukey.

$a, b$ Means, in a collumn, followed by different small letters differ $(P<.05)$ by Tukey test.

pastejo $(0,605 \mathrm{~kg})$, quando a qualidade da forragem foi menor que as obtidas nas demais avaliações, motivados pela alta massa de forragem que continha folhas envelhecidas. Além disso, a elevada carga animal utilizada no primeiro período para o ajuste da lotação proporcionou menor oportunidade de seleção de forragem, influenciando negativamente o desempenho animal.

O GMD de $0,928 \mathrm{~kg}$ obtido no capim-elefante foi superior ao obtido por Portela et al. (1995), que obtiveram ganhos de $0,755 \mathrm{~kg}$, usando novilhas da raça Holandês, e por Lima et al. (1969a,b), que obtiveram ganhos de 0,462 e $0,512 \mathrm{~kg}$, respectivamente. Almeida et al. (2000a), trabalhando com oferta de forragem de 3,$8 ; 7,5 ; 10,2$; e $14,0 \%$ em capimelefante anão "Mott", correspondendo a $722 \pm 104$; $1537 \pm 65 ; 2332 \pm 2$ e $2542 \pm 36 \mathrm{~kg}$ de MS de lâminas verdes, obtiveram ganho de peso médio diário de 0,$829 ; 1,011 ; 1,042$ e 1,034 kg usando novilhos de 8 a 10 meses de idade das raças Charolês, Nelore e suas cruzas. Analisando o ganho de peso obtido neste trabalho, nota-se leve inferioridade aos ganhos obtidos por Almeida et al. (2000b) em ofertas de forragem de lâminas verdes e valor nutritivo superiores aos $1168 \mathrm{~kg}$ de MS de lâminas verdes, aos $10,1 \%$ de proteína bruta e aos 57,8\% de DIVMS na matéria seca das folhas. Isso mostra que a disponibilidade de MS de lâminas verdes usada neste experimento pode estar abaixo da ideal para propiciar maior ganho de peso médio diário por animal.

O papuã apresentou GMD de 1,054 kg, sendo superior ao obtido por Martins et al. (2000), que utilizaram animais cruzas Charolês e Hereford com idade semelhante aos usados nesse trabalho, em que se avaliaram as doses de 0,100 e $200 \mathrm{~kg} / \mathrm{ha}$ de nitrogênio e obtiveram na média GMD de $0,850 \mathrm{~kg}$. O menor ganho de peso obtido por Martins et al. (2000) pode ser atribuído à elevada disponibilidade de forragem usada (14\%), o que causou acúmulo de material de baixo valor nutritivo.

Não foi observada diferença significativa no GMD entre as pastagens de milheto e sorgo (1,188 e 1,121 kg), somente houve diferença numérica de 67 gramas/dia a favor do milheto. Esses resultados concordam com os obtidos por Cóser \& Maraschin (1981), os quais também não encontraram diferença no GMD entre milheto e sorgo. Semelhanças no GMD entre milheto e sorgo também foram relatados por Utley et al. (1976) e Dunavin (1970), porém os GMD obtidos por esses autores foram inferiores aos obtidos no presente experimento. Os ganhos de peso semelhantes entre milheto e sorgo são perfeitamente explicáveis pela semelhança na disponibilidade e na qualidade da forragem de ambas as pastagens.

Os resultados obtidos no milheto foram superiores aos encontrados por Lupatini (1996), que, trabalhando com níveis de $\mathrm{N}$ em milheto, obteve ganho médio diário de $1,052 \mathrm{~kg}$ na média dos níveis de $\mathrm{N}$, e por Restle et al. (1994), que obtiveram GMD de $0,720 \mathrm{~kg}$ como média de dois grupos de pastejo, desponte e seguidor, em pastejo rotativo, sem aplicação de nitrogênio. A superioridade no GMD é mais evidente quando comparada aos dados obtidos por Moojen et al. (1999), que utilizaram novilhos de 13-14 meses, para avaliar o efeito de níveis de 0,150 e $300 \mathrm{~kg} / \mathrm{ha}$ 
de nitrogênio em pastagem de milheto, e obtiveram ganhos de 0,$553 ; 0,659$; e $0,764 \mathrm{~kg}$, observando aumento linear de acordo com o incremento nas doses de nitrogênio. Já Moraes \& Maraschin (1988), utilizando novilhos cruzas Charolês e Nelore, com pressão de pastejo de 4 e 10\%, obtiveram GMD de 0,5 e 1,24 kg, respectivamente. Verifica-se que os dados do presente trabalho são semelhantes aos maiores ganhos obtidos e na maior pressão de pastejo, confirmando a importância de uma relação adequada entre disponibilidade e qualidade de forragem, visando o máximo ganho de peso por animal, em função do aproveitamento do potencial genético.

O sorgo apresentou baixo desempenho no último período de pastejo, sendo inferior aos obtidos nas demais pastagens, devido basicamente à baixa disponibilidade de folhas e grande presença de colmos observada naquele período, embora a disponibilidade total de MS fosse semelhante às obtidas nas demais pastagens.

$\mathrm{Na}$ Tabela 4 encontram-se os resultados referentes à carga animal suportada pelas pastagens cultivadas nos períodos de utilização e na média do período experimental. Não foi observada diferença significativa na carga animal suportada pelas pastagens. No entanto, houve inferioridade numérica do sorgo em relação às demais pastagens, o que pode ter sido motivado pela expressiva participação de inços na pastagem.

A pastagem de capim-elefante caracterizou-se por manter por longo período o mesmo número de animais, como pode ser observado a partir do segundo período até o final do experimento, sendo que o aumento verificado na carga animal deve-se exclusivamente ao ganho de peso dos animais, pois o número permaneceu o mesmo. Estes resultados são de elevada importância para propriedades que usam pastagem de capim-elefante, pois consegue-se manter por longos períodos o mesmo número de animais, sem haver necessidade de entrada e saída de animais para ajustar a carga animal à produção de forragem. No primeiro período de pastejo, foi necessária a colocação de elevada carga animal para manter a massa de forragem pretendida, devido à alta taxa de acúmulo de MS do período. Na média do período experimental, a carga animal média suportada pela pastagem foi de $1682 \mathrm{~kg} \mathrm{de} \mathrm{PV/ha,} \mathrm{sendo} \mathrm{semelhante} \mathrm{às} \mathrm{obtidas} \mathrm{por}$ Almeida et al. (2000b), em capim-elefante anão cv. "Mott", nas ofertas de forragem de 7,5 e 10,2 kg de matéria seca de lâminas verdes/100 kg de PV/dia.

A carga animal média suportada pela pastagem de capim-elefante foi inferior às obtidas com vacas Holandês em lactação (Olivo et al., 1992; Ruviaro, 1994; Diefenbach, 1994), esta diferença ocorreu basicamente em função das vacas receberem suplementação com concentrado no cocho, o que diminui o consumo de forragem, com conseqüente aumento na carga animal. Por outro lado, os resultados foram superiores aos obtidos por Lourenço et al. (1978), que, utilizando novilhos zebu, obtiveram carga de $1000 \mathrm{~kg}$ de PV/ha, sem utilização de nitrogênio em cobertura.

A pastagem de papuã suportou uma carga de $1634 \mathrm{~kg}$ de peso vivo/ha, sendo superior às encontradas por Martins et al. (2000), que testaram níveis de 0 , 100 e $200 \mathrm{~kg}$ de nitrogênio/ha e obtiveram cargas de 717, 930 e $1118 \mathrm{~kg}$ de PV/ha.

Os resultados de carga animal obtidos nas pastagens de milheto e sorgo foram semelhantes as encontra-

Tabela 4 - Carga animal (kg PV/ha) suportada pelas diferentes pastagens de estação quente Table 4 - Stocking rate ( $k g$ LW/ha) supported by the different summer pastures

\begin{tabular}{|c|c|c|c|c|c|c|}
\hline \multirow[b]{2}{*}{$\begin{array}{l}\text { Pastagens } \\
\text { Pastures }\end{array}$} & \multicolumn{5}{|c|}{$\begin{array}{l}\text { Períodos } \\
\text { Periods }\end{array}$} & \multirow[t]{2}{*}{$\begin{array}{l}\text { Média ponderada } \\
\text { Weighed mean }\end{array}$} \\
\hline & 1 & 2 & 3 & 4 & 5 & \\
\hline $\begin{array}{l}\text { Capim-elefante } \\
\text { Elephantgrass }\end{array}$ & 3039 & 1104 & 1244 & 1379 & 1498 & 1682 \\
\hline $\begin{array}{l}\text { Papuã } \\
\text { Alexandergrass }\end{array}$ & - & 1097 & 2361 & 1614 & 1226 & 1634 \\
\hline $\begin{array}{l}\text { Sorgo } \\
\text { Sorghum }\end{array}$ & - & 1272 & 1416 & 1496 & 1353 & 1389 \\
\hline $\begin{array}{l}\text { Milheto } \\
\text { Millet }\end{array}$ & - & 1082 & 1908 & 1511 & 1596 & 1514 \\
\hline
\end{tabular}

$\mathrm{P}>0,05(P>05)$. 
dos por Cóser \& Maraschin (1981) em milheto (1387 $\mathrm{kg}$ ) e sorgo (1277 kg de PV), que trabalharam com 60 $\mathrm{kg}$ de nitrogênio/ha, sendo semelhantes também à carga animal encontrada por Moojen et al. (1999), no nível zero de nitrogênio, e inferiores às obtidas pelo mesmo autor nos níveis 150 e $300 \mathrm{~kg}$ de N/ha, de 2399 e 2780 $\mathrm{kg}$, respectivamente. Considerando que foram utilizados $300 \mathrm{~kg}$ de N/ha, esperava-se uma semelhança na mesma dose, mas, em função do percentual elevado de inços e das más condições de drenagem da área, os valores obtidos foram inferiores. A carga animal do milheto também foi inferior à obtida por Lupatini (1996), quando utilizou a dose de $300 \mathrm{~kg}$ de N/ha.

$\mathrm{Na}$ Tabela 5 encontram-se os resultados obtidos referentes ao ganho de peso vivo/ha. Analisando o período total de pastejo, verifica-se que não houve diferença significativa no ganho de peso/ha entre as espécies. No entanto, a pastagem de capim-elefante apresentou superioridade numérica no ganho de peso/ha, sendo 15,84; 35,79; e 21,02\% superiores ao papuã, sorgo e milheto, respectivamente. Essa superioridade ocorreu em função de o capim-elefante ser uma espécie perene, o que proporcionou maior período de utilização, enquanto o menor ganho de peso verificada na pastagem de sorgo se deve, principalmente, ao baixo GMD obtido noúltimo período e à tendência de menores cargas suportadas pela pastagem.

Resultados inferiores para ganho de peso/ha na pastagem de sorgo, quando comparados com a pastagem de milheto, também foram encontrados por Dunavin (1970), Utley et al. (1976), Mccarter \& Rouquete Jr. (1977) e Cóser \& Maraschin (1981).

O ganho de peso vivo/ha obtido na pastagem de papuã foi numericamente superior aos ganhos obtidos nas pastagens de sorgo e milheto, sendo essa superioridade de 17,22 e 4,47\%, respectivamente. Esses resultados demonstram a importância da utilização do papuã como pastagem, pois, além de ser uma espécie de verão com ressemeadura espontânea, principalmente em áreas previamente utilizadas com culturas anuais de verão, apresenta também elevado potencial de produção de forragem e animal.

O ganho de peso vivo/ha obtido neste trabalho, na pastagem de papuã, foi superior aos obtidos por Martins et al. (2000), utilizando níveis crescentes de $\mathrm{N}(0,100$ e $200 \mathrm{~kg} / \mathrm{ha})$, que obtiveram ganhos de 209 , 297 e $354 \mathrm{~kg} / \mathrm{ha}$, respectivamente. A superioridade no ganho de peso/ha foi motivada pelo maior GMD e pela maior carga animal, que ocorreu em função de um manejo mais adequado da pastagem.

Os ganhos de peso/ha obtidos na pastagem de milheto e sorgo foram superiores aos obtidos por Cóser \& Maraschin (1981), que obtiveram 401 e $479 \mathrm{~kg} / \mathrm{ha}$, e por Utley et al. (1976), que alcançaram valores de 376 e $525 \mathrm{~kg} / \mathrm{ha}$ para sorgo e milheto, respectivamente. Já o ganho de peso/ha obtido na pastagem de milheto foi semelhante ao obtido por Moojen et al.(1999), utilizando $300 \mathrm{~kg}$ de N/ha, e bem inferior ao obtido por Lupatini (1996), também empregando a dose de $300 \mathrm{~kg}$ de N/ha em milheto.

Na Tabela 6 encontra-se a evolução do peso dos animais, durante a fase de realização do experimento, nas diferentes pastagens.

Observa-se que os animais pastejando capimelefante apresentaram superioridade no peso final em relação aos demais, mesmo tendo apresentado

Tabela 5 - Ganho de peso vivo(kg/ha) obtido em diferentes pastagens de estação quente Table 5 - Live weight gain ( $\mathrm{kg} / \mathrm{ha}$ ) obtained in different summer pastures

\begin{tabular}{|c|c|c|c|c|c|c|}
\hline \multirow[b]{2}{*}{$\begin{array}{l}\text { Pastagens } \\
\text { Pastures }\end{array}$} & \multicolumn{5}{|c|}{$\begin{array}{c}\text { Períodos } \\
\text { Periods }\end{array}$} & \multirow[b]{2}{*}{$\begin{array}{l}\text { Total } \\
\text { Total }\end{array}$} \\
\hline & 1 & 2 & 3 & 4 & 5 & \\
\hline $\begin{array}{l}\text { Capim-elefante } \\
\text { Elephantgrass }\end{array}$ & 259,0 & 139,9 & 139,5 & 130,9 & 105,1 & 774,4 \\
\hline $\begin{array}{l}\text { Papuã } \\
\text { Alexandergrass }\end{array}$ & - & 118,5 & 315,6 & 154,8 & 79,6 & 668,5 \\
\hline $\begin{array}{l}\text { Sorgo } \\
\text { Sorghum }\end{array}$ & - & 190,2 & 199,4 & 158,9 & 21,8 & 570,3 \\
\hline $\begin{array}{l}\text { Milheto } \\
\text { Millet }\end{array}$ & - & 178,0 & 242,3 & 156,1 & 63,5 & 639,9 \\
\hline
\end{tabular}

$\mathrm{P}>0,05(P>05)$. 
Tabela 6 - Evolução do peso de novilhos mantidos em pastagem cultivada de estação quente Table 6 - Weight of beef steers kept in summer grasses pasture

\begin{tabular}{|c|c|c|c|c|c|c|}
\hline \multirow[b]{2}{*}{$\begin{array}{l}\text { Pastagens } \\
\text { Pastures }\end{array}$} & \multicolumn{6}{|c|}{$\begin{array}{l}\text { Pesagens } \\
\text { Weights }\end{array}$} \\
\hline & 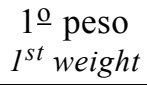 & $\begin{array}{c}2^{\underline{o}} \text { peso } \\
2^{\text {nd }} \text { weight }\end{array}$ & 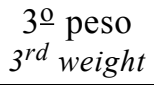 & $\begin{array}{c}4^{\mathrm{o}} \text { peso } \\
4^{\text {th }} \text { weight }\end{array}$ & $\begin{array}{c}5 \underline{\mathrm{o}} \text { peso } \\
5^{\text {th }} \text { weight }\end{array}$ & $\begin{array}{l}\text { Peso final } \\
\text { Final weigh }\end{array}$ \\
\hline $\begin{array}{l}\text { Capim-elefante } \\
\text { Elephantgrass }\end{array}$ & 209 & 228 & 259 & 290 & 319 & 342 \\
\hline $\begin{array}{l}\text { Papuã } \\
\text { Alexandergrass }\end{array}$ & & 211 & 235 & 268 & 295 & 315 \\
\hline $\begin{array}{l}\text { Sorgo } \\
\text { Sorghum }\end{array}$ & & 212 & 249 & 286 & 317 & 322 \\
\hline $\begin{array}{l}\text { Milheto } \\
\text { Millet }\end{array}$ & & 214 & 252 & 286 & 317 & 330 \\
\hline
\end{tabular}

ganho de peso médio diário inferior. Essa superioridade ocorreu devido ao maior período de pastejo proporcionado pelo capim-elefante, pelo fato de ser uma pastagem perene que apresenta rápido crescimento inicial, quando a temperatura se eleva e o fotoperíodo aumenta. A rápida produção de forragem do capim-elefante na primavera preenche o vazio de pastagens cultivadas existente entre a produção das pastagens cultivadas anuais de estação fria e as cultivadas de estação quente. Isso faz com que os animais que saem das pastagens de estação fria entrem direto no capim-elefante, não passando por um período de campo nativo, que provoca uma parada no seu desempenho.

Os animais que pastejaram capim-elefante, por apresentarem maior peso final em relação aos demais, necessitam de menor período subseqüente para terminação, proporcionando maior rapidez e flexibilidade para sua comercialização.

\section{Conclusões}

As pastagens de capim-elefante, milheto, sorgo forrageiro e papuã, quando manejadas adequadamente, possibilitaram obter altos ganho de peso médio diário em novilhos de sobreano.

Os animais pastejando sorgo ou milheto apresentaram ganho de peso médio diário semelhantes, sendo superiores aos obtidos no capim-elefante, ficando o papuã em posição intermediária.

O ganho de peso vivo e a carga animal porhectare suportada pelas pastagens de capim-elefante, papuã, sorgo e milheto foram semelhantes.

O papuã é uma espécie que apresenta elevado potencial de produção animal e de forragem, se manejado e adubado corretamente.

O capim-elefante, por ser uma espécie perene, apresenta crescimento primaveril, preenchendo o vazio forrageiro que ocorre no período de utilização entre as pastagens anuais de estação fria e anuais de estação quente.

\section{Literatura Citada}

ALMEIDA, E.X.; MARASCHIN, G.E.; HARTHMANN, O.E.L. et al. Oferta de forragem de capim-elefante anão "Mott" e dinâmica da pastagem. Revista Brasileira de Zootecnia, v.29, n.5, p.1281-1287, 2000a.

ALMEIDA, E.X.; MARASCHIN, G.E.; HARTHMANN, O.E.L. et al. Oferta de forragem de capim-elefante anão "Mott" e rendimento animal. Revista Brasileira de Zootecnia, v.29, n.5, p.1288-1295, 2000b.

ANUALPEC. Anuário estatístico da produção animal. FNP. São Paulo: Camargo Soares Ltda, 2000. 392p.

ALVES FILHO, D.C. Evolução do peso e desempenho anual de um rebanho de cria, constituído por fêmeas de diferentes grupos genéticos. Santa Maria: Universidade Federal de Santa Maria, 1995. 131p. Dissertação (Mestrado em Zootecnia) - Universidade Federal de Santa Maria, 1995.

BLASER, R.E. Symposium on forage utilization: Effects of fertility levels and stage of maturity on forage nutritive value. Journal of Animal Science, v.23, p.246-253, 1964.

COSER, A.C.; MARASCHIN, G.E. 1983. Desempenho animal em pastagem de milheto comum e sorgo. Pesquisa Agropecuária Brasileira, v.18, n.4, p.421-426, 1983.

COSER, A.C.; MARASCHIN, G.E. Produção e qualidade de forragem de milheto comum e sorgo cv. Sordan NK sob pastejo. Pesquisa Agropecuária Brasileira, v.16, n.3, p.397-403, 1981.

DIEFENBACH, J. Avaliação de cultivares de capim elefante (Pennisetum purpureum Schum). sob pastejo com vacas em leiteiras. Santa Maria: Universidade Federal de Santa Maria, 1994. 121p. Dissertação (Mestrado em Zootecnia), Universidade Federal de Santa Maria, 1994.

DUNAVIN, L.S. Gahi-1 pearl millet and two sorghum x sudangrass 
hibrids as pasture for yearling beef cattle. Agronomy Journal, v.2, n.3, p.375-377, 1970.

KESSLER, J.P.M.C. Pastejo contínuo em capim-elefante (Pennisetum purpureum Schum.) com vacas em lactação, sob níveis distintos de folha residual. Santa Maria: Universidade Federal de Santa Maria, 1995. 83p. Dissertação (Mestrado em Zootecnia) - Universidade Federal de Santa Maria, 1995.

LANÇANOVA, J.A.C.; RESTLE, J.; SANTOS, G.L. Digestibilidade e produção de matéria seca digestível do capim papuã (Brachiaria plantaginea (Link) Hitchc) sob efeito de frequências de corte e nitrogênio. Ciência Rural, v.18, n.3-4, p.319-327, 1988a.

LANÇANOVA, J.A.C.; RESTLE, J.; SANTOS, G.L. Produção e qualidade do capim papuã (Brachiaria plantaginea (Link) Hitchc) sob efeito de frequências de corte e nitrogênio. Ciência Rural, v.18, n.3-4, p.343-354,1988b.

LIMA, F.P.; MARTINELLI, D.; SARTINI, H.J. et al. Pastejo competitivo entre quatro gramíneas tropicais em Latossolo roxo, na engorda de bovinos da raça Nelore. Boletim Informativo Animal, v.26, p.189-197, 1969a.

LIMA, F.P.; SARTINI, H.J.; MARTINELLI, D. et al. 1969b. Utilização de quatro gramíneas tropicais na produção de carne, em um solo típico Latossolo roxo. Boletim Informativo Animal, v.26, p.199-214, 1969b.

LOURENÇO, A.J.; SARTINI, H.J.; SANTAMARIA, M. et al. Estudo comparativo entre três níveis de fertilização nitrogenada e consorciada com leguminosas em pastagem de capim elefante Napier (Pennisetum purpureum Schum.) na determinação da capacidade de suporte. Boletim Informativo Animal, v.35, n.1, p.69-80, 1978.

LUPATINI, G.C. Produção animal em milheto (Pennisetum americanum (L.) Leeke) submetido a níveis de adubação nitrogenada. Santa Maria: Universidade Federal de Santa Maria, 1996. 126p. Dissertação (Mestrado em Zootecnia) Universidade Federal de Santa Maria, 1996.

LUPATINI, G.C.; MOOJEM, E.L.; RESTLE, J. Resposta do milheto (Pennisetum americanum (L.) Leeke) sob pastejo à adubação nitrogenada. Pesquisa Agropecuária Brasileira, v.31, n.10, p.715-720, 1996.

MARTINS, J.D.; RESTLE, J.; BARRETO, I.L. Produção animal em capim papuã (Brachiaria plantaginea (Link) Hitchc) submetido a níveis de nitrogênio. Ciência Rural, v.30, n.5, p.887-892, 2000.

McCARTER, M.M.; ROUQUETTE Jr., F.M. Grazing pressures and animal performance from millet. Agronomy Journal, v.69, n.6, p.983-987, 1977.

MOOJEN, E.L.; LUPATINI, G.C.; RESTLE, J. et al. Produção animal em pastagem de milheto sob diferentes níveis de nitrogênio. Pesquisa Agropecuária Brasileira, v.34, n.11, p.2145-2149, 1999.

MORAES, A.; MARASCHIN, G.E. Pressões de pastejo e produção animal em milheto cv. comum. Pesquisa Agropecuária Brasileira, v.23, n.2, p.197-205, 1988.

MORENO, J.A. Clima do Rio Grande do Sul. Porto Alegre: Secretaria da Agricultura. 1961. 41p

MOTT, G.O.; LUCAS, H.L. The design conduct and interpretation of grazing trials on cultivated and improved pastures. In: INTERNATIONAL GRASSLAND CONGRESS, 6., 1952, Pensylvania. Proceedings... Pensylvania: State College Press, 1952. p.1380-1395.

MUEHLMANN, L.D.; ROCHA, M.G.; RESTLE, J. Utilização de pastagem de estação quente com bovinos desmamados precocemente. Revista Brasileira de Zootecnia, v.26, n.3, p.584-589, 1997.
NATIONAL RESEARCH COUNCIL - NRC. Nutrient requirement of beef cattle. 6.ed. Washington, National Academy Press, 1966. 90p.s

OLIVO, C.J.; MOREIRA, J.C.S.; BARRETO, I.L. Utilização de pastagens de capim elefante e capim setária como base da alimentação de vacas em lactação, durante o verão. Revista Brasileira de Zootecnia, v.21, n.3. p.347-352, 1992.

PORTELA, J.N.; OLIVO, C.J.; MICHELON, E. et al. Desempenho de novilhas e vacas em lactação submetidas ao pastejo em cultivares de capim elefante. In: REUNIÃO ANUAL DA SOCIEDADE BRASILEIRA DE ZOOTECNIA, 32., 1995, Brasília. Anais... Brasília: Sociedade Brasileira de Zootecnia, 1995. p.127-129.

RESTLE, J.; AITA, V.; LUPATINI, G.C. et al. Desempenho de novilhos de dois grupos genéticos sob pastejo rotativo. In: REUNIÃO ANUAL DA SOCIEDADE BRASILEIRA DE ZOOTECNIA, 31., 1994, Maringá. Anais... Maringá: Sociedade Brasileira de Zootecnia, 1994. p.276.

RESTLE, J.; FERREIRA, M.V.B.; SOARES, A.B. et al. Produção animal em pastagem nativa ou cultivada durante o período de verão. In: REUNIÃO ANUAL DA SOCIEDADE BRASILEIRA DE ZOOTECNIA, 33., 1996, Fortaleza. Anais... Viçosa, MG: Sociedade Brasileira de Zootecnia, 1996. p.438-440.

ROSO, C.; RESTLE, J. Aveia preta, triticale e centeio em mistura com azevém. 2. Produtividade animal e retorno econômico. Revista Brasileira de Zootecnia, v. 29, n.1, p.85-93, 2000.

ROSO, C.; RESTlE, J.; SOARES, A.B. et al. Aveia preta, triticale e centeio em mistura com azevém. 1. Dinâmica produção e qualidade de forragem. Revista Brasileira de Zootecnia, v. 29, n.1, p.75-84, 2000.

RUVIARO, C. Desempenho de vacas em lactação submetidas ao pastejo em cultivares de capim elefante (Pennisetum purpureum Schum). Santa Maria: Universidade Federal de Santa Maria, 1994. 111p. Dissertação (Mestrado em Zootecnia) - Universidade Federal de Santa Maria, 1994.

SAS. Language reference. Version 6, Cary: SAS Institute Inc., 1990. 1042p.

UTLEY, P.R.; MARCHANT, W.H.; McCORMICK, W.C. Evaluation of annual grass forages in prepared seedbeds and overseeded into perennial sods. Journal of Animal Science, v.42, n.1, p.16-20, 1976.

VAZ, R.Z. Desenvolvimento e desempenho reprodutivo de novilhas de corte submetidas a diferentes níveis de suplementação durante o período reprodutivo aos 14 meses de idade. Santa Maria: Universidade Federal de Santa Maria, 1998. 98p. Dissertação (Mestrado em Zootecnia) Universidade Federal de Santa Maria, 1998.
Recebido em: 29/06/01

Aceito em: 15/05/02 